\title{
ISOLASI DAN IDENTIFIKASI SENYAWA KIMIA FENOLIK DALAM EKSTRAK ETIL ASETAT KULIT BUAH JENGKOL
}

\author{
Ahmad Sopian ${ }^{1}$, Ahmad Darmawan ${ }^{2}$, Partomuan Simanjuntak ${ }^{3}$. \\ 1 \\ Magister Farmasi, Universitas Pancasila, Email: ahmadsopain0191@gmail.com \\ ${ }^{2}$ Laboratorium Kimia Bahan Alam, Pusat Penelitian Kimia Lembaga Ilmu \\ Pengetahuan Indonesia (LIPI). \\ 3 Laboratorium Kimia Bahan Alam, Pusat penelitian Bioteknologi. Lembaga Ilmu \\ Pengetahuan Indonesia (LIPI)
}

\begin{abstract}
Abstrak
Jengkol (Archidendron pauciflorum (Benth.) I.C Nielsen) merupakan tanaman yang sudah tidak asing lagi di Indonesia dan banyak digunakan sebagai pangan olahan yang cukup digemari. Salah satu bagian tanaman jengkol yang kurang dimanfaatkan adalah kulitnya. Kulit buah jengkol mengandung senyawa alkaloid, flavonoid, tannin, glikosida, sapoinin dan steroid atau triterpenoid. Tujuan penelitian ini adalah untuk mengetahui kandungan senyawa kimia dalam ekstrak etil asetat kulit buah jengkol, dan menguji aktivitas antioksidan dengan metode peredaman radikal bebas DPPH.

Hasil isolasi, pemurnian dalam ekstrak etil asetat kulit buah jengkol tidak memberikan aktivitas sebagai antioksidan. Hasil analisis menggunakan spektrofotometri FTIR, kromatografi GasSpektrometri Massa (KG-SM) dan Spektroskopi Nuclear Magnetic Resonance ( $\left.{ }^{1} \mathrm{HNMR}\right)$.
\end{abstract}

Kata Kunci : Kulit Buah Jengkol, Archidendron pauciflorum (Benth.) I.C Nielsen, Leguminosae, (1-(2,6-dihidroksi,4metoksi fenil) dekana-1-one)

\begin{abstract}
Jengkol (Archidendron pauciflorum (Benth.) I.C Nielsen) is a plant that is already familiar in Indonesia and is widely used as a processed food that is quite popular. One of the underutilized parts of the jengkol plant is the skin. Jengkol fruit peel contains alkaloid compounds, flavonoids, tannins, glycosides, sapoinin and steroids or triterpenoids. The purpose of this study was to determine the content of chemical compounds in ethyl acetate extract of jengkol fruit peel, and to test antioxidant activity by DPPH free radical reduction method.

The results of isolation, purification in ethyl acetate extract of jengkol fruit skin does not provide activity as an antioxidant. The results of the analysis using FTIR spectrophotometry, Gas chromatography-Mass Spectrometry (GC-MS) and Nuclear Magnetic Resonance Spectroscopy $\left({ }^{1} H N M R\right)$.
\end{abstract}

Keywords: Antioksidan , archidendron pauiflorum (Benth) I.C Nielsen, jengkol, (1- (2,6-dihydroxy, 4methoxy phenyl) decane-1-one) 


\section{PENDAHULUAN}

Obat herbal dipakai secara luas di hampir seluruh negara di dunia. Menurut WHO, negara di Asia dan Amerika Latin menggunakan obat herbal sebagai pelengkap pengobatan primer yang mereka terima. Bahkan di Afrika, sebanyak $80 \%$ dari populasi menggunakan obat herbal untuk pengobatan primer. Indonesia dikenal sebagai negara dengan sumber daya hayati kedua terbesar yang tersebar dari Sabang hingga Merauke (WHO, 2003). Dalam Kotranas BPOM di Indonesia terdapat lebih kurang 30.000 jenis tumbuh-tumbuhan, lebih kurang 7.500 jenis diantaranya termasuk tanaman berkhasiat obat, salah satunya adalah tumbuhan jengkol yang merupakan tumbuhan khas di wilayah Asia Tenggara. Bijinya digemari di Malaysia, Thailand, dan Indonesia sebagai bahan pangan. Tumbuhan ini juga banyak ditemukan di Malaysia dan Thailand. Namun, asal-usul tanaman jengkol tidak diketahui dengan pasti. Di Sumatera, Jawa Barat, dan Jawa Tengah, tumbuhan jengkol banyak ditanam di kebun atau pekarangan secara sederhana (Kontranas, 2006)

Tumbuhan jengkol suku Fabaceae, yang sudah sejak lama ditanam di Indonesia, di kebun atau pekarangan. Buah jengkol mengandung karbohidrat, protein, vitamin $\mathrm{A}$, vitamin $\mathrm{B}$, fosfor, kalsium, alkaloid, minyak atsiri, steroid, glikosida, tanin, dan saponin. Biji jengkol merupakan bagian tanaman yang paling banyak dimanfaatkan sebagai bahan makanan dan obat. Sebagai obat, biji jengkol dapat membantu memperlancar proses buang air besar karena jengkol mengandung serat yang tinggi (Anonim, 2009).

Radikal bebas adalah atom atau molekul yang memiliki elektron tidak berpasangan (unpaired electron). Adanya elektron yang tidak berpasangan menyebabkan senyawa tersebut sangat reaktif mencari pasangan, sehingga akan terbentuk radikal baru lagi dan seterusnya sampai terjadi reaksi berantai. Reaksi ini akan terus berlanjut sampai reaktivitasnya diredam oleh senyawa yang bersifat antioksidan (Winarsi, 2007).

Radikal bebas hanya bisa diatasi dengan antiokisdan yang berperan sebagai inhibitor penghambat oksidasi 
dengan cara bereaksidengan radikal bebas reaktif yang membentuk radikal bebas tak reaktif yang relatif stabil (Sofia, 2003).

Menurut penelitian sebelumnya telah diketahui bahwa dalam kulit buah jengkol menunjukkan adanya senyawa golongan alkaloid, flavonoid, tanin, glikosida, saponin, steroid/triterpenoid. Kulit buah jengkol umumnya dikategorikan sebagai limbah, khususnya di pasar tradisional dan dianggap tidak mempunyai nilai ekonomis (Nurussakinah, 2010).

Berdasarkan hasil penelitian yang dilakukan Surya Alfian tentang analisis aktivitas antioksdian ekstrak kulit jengkol (pithecellobium jiringa) dengan tiga pelarut yang berbeda kepolarannya dimana $\mathrm{IC}_{50}$ dengan waktu maserasi selama 24 jam dan mendatakan aktivitas antioksidan pada ekstrak metanol sebesar 51,1979 $\mu \mathrm{g} / \mathrm{mL}$ (Surya, 2017).

Menurut penelitian sebelumnya Verdiani Devi tentang isolasi dan identifikasi senyawa antioksidan dari ekstrak etanol 96\% kulit buah jengkol (Archidendron pauciflorium (Benth) I.C Nilesen) diketahui bahwa mempunyai senyawa metil galat (Metil 3,4,5trihidroksibenzoat) (Verdiani, 2018).

Berdasarkan uraian latar belakang diatas, maka peneliti tertarik untuk melakukan penelitian lanjutan terhadap ekstrak kulit buah jengkol, dengan tujuan untuk mengisolasi, mengidentifikasi kandungan senyawa dalam kulit buah jengkol yang berpotensi sebagai antioksidan serta untuk mengetahui aktivitas antioksidan terhadap ekstrak, fraksi, dan senyawa murni dan untuk mengidentifikasi struktur kimia isolat hasil proses isolasi yang diperolah dari ekstrak etil asetat kulit buah jengkol.

\section{METODE PENELITIAN}

\section{- Bahan}

Ekstrak etil asetat kulit buah jengkol (Archidendron pauciflorum (Benth.) I.C Nielsen) diperoleh dari LIPI Cibinong 6,07 gram.

\section{- Alat}

Alat-alat yang digunakan dalam penelitian ini adalah alat-alat gelas (Kolom Kromatografi, Corong Pisah, Tabung Reaksi, Labu Ukur, 
Erlenmeyer, Mikropipet, Pipa Kapiler, Cawan Penguap) Spektrofotometer FTIR (Merck, shimadzu FTIR8400S), spektrofotometer UVVis (Merck, HITACHI U3900H), GC-MS (Merck, agilent Technologies 5975C inert MSD, 7890A GC System), Sonikator (Merck, Branson1550), Timbangan Analitik (Merck, Precisa 2A0A), Lempeng Silika Gel, $\mathrm{GF}_{254}$, Inkubator (Merck, memmert), Homogenizer, TLC Lamp, Hot plate, , Kertas Saring, Alumunium Foil, Batang Pengaduk, Spatula, Vial.

\section{- Penyiapan Ekstrak}

Bahan yang digunakan pada penelitian ini adalah ekstrak etil asetat kulit buah jengkol (Archidendron pauciflorum (Benth.) I.C Nielsen).

\section{- Isolasi dan Pemurnian}

Sebanyak 6,07 gram ektrak etil asetat kulit jengkol dilakukan fraksinasi dengan kromatografi kolom siika gel. Fase gerak yang digunakan yaitu $n$-heksan - etil asetat $(5: 1) \sim(1: 1)$, etil asetat, metanol. Hasil fraksinasi kromatografi kolom pertama diperoleh 7 frkasi kemudian ke 7 fraksi diuji aktivitas antioksidan dengan menggunakan metode peredaman radikal bebas DPPH. selanjutnya Fraksi 7.3 yang diperoleh dimurnikan menggunakan KLT preparatif dengan eluen DCM:MeOH (10:1) dan menghasilkan isolat 7.3.1.

\section{- Uji aktivitas Antioksidan metode peredaman radikal bebas}

a. Pembuatan larutan blangko DPPH

Reagen DPPH (BM 394,32) ditimbang seksama sebanyak lebih kurang 1,6 mg, dimasukan kedalam labu ukur $10 \mathrm{ml}$, dilarutkan dengan methanol pro analisis hingga tanda, dihomogenkan, kemudian dimasukan kedalam botol coklat. Untuk setiap pengujian larutan dibuat baru.

b. Pembuatan larutan blangko

Larutan DPPH 0,4 mM dipipet sebanyak $600 \mathrm{uL}$, dimasukkan kedalam tabung reaksi yang telah ditera $3 \mathrm{~mL}$, kemudian ditambahkan metanol pro analitik hingga tanda, lalu 
dihomogenkan, mulut tabung ditutup rapat dan diinkubasi

c. Pembuatan larutan uji

$\begin{array}{lr}\text { Ekstrak } & \text { Kulit } \quad \text { buah } \\ \text { jengkol } & \text { ditimbang }\end{array}$
seksama sebanyak lebih kurang 1,3 mg, kemudian dimasukkan kedalam labu terukur $\quad 10 \quad \mathrm{~mL}$. ditambahkan metanol pro analisis hingga $2,6 \mathrm{~mL}$ sehingga diperoleh larutan uji dengan konsentrasi 500 $\mathrm{ug} / \mathrm{mL}$ sebagai larutan induk. Larutan induk tersebut dipipet $30 \mathrm{ul}, 60$ ul, 100 ul, 300 ul, 600 ul.

d. Pengukuran serapan

Larutan uji, larutan blangko diinkubasi pada suhu $37^{0} \mathrm{C}$ selama 30 menit, serapan larutan diukur pada panjang gelombang $\quad 517 \quad \mathrm{~nm}$ dengan menggunakan spektrofotometri UV-Vis.

$\%$ hambatan $=\frac{\text { serapan blanko }- \text { serapan larutan } u j i}{\text { serapan blanko }} \times 100$
Ditentukan fraksi mana yang memiliki aktivitas antioksidan tertinggi.

\section{HASIL DAN PEMBAHASAN}

- Hasil uji aktivitas antioksidan

\section{F-EA.7 hasil kromatografi}

\section{kolom}

Untuk mengetahui aktivitas antioksidan didalam ekstrak etil aseatat kulit buah jengkol maka dilakukan uji dengan metode peredamn radikal bebas hasil uji bisa dilihat pada Tabel 1.

Tabel 1. Persen Hambat Uji

\section{Antioksidan 1}

\begin{tabular}{|c|c|c|}
\hline NO & SAMPEL & $\begin{array}{c}\text { PEREDASMAN } \\
(\%)\end{array}$ \\
\hline 1 & F-EA.1 & 86,87 \\
\hline 2 & F-EA2 & 12,96 \\
\hline 3 & F-EA.3 & 12,61 \\
\hline 4 & F-EA.4 & 12,96 \\
\hline 5 & F-EA.5 & 12,78 \\
\hline 6 & F-EA.6 & 93,64 \\
\hline 7 & F-EA.7 & 85,87 \\
\hline
\end{tabular}

Berdasarkan hasil dari uji aktivitas antioksidan dengan metode peredaman radikal bebas DPPH menunjukkan bahwa fraksi yang memiliki aktivitas antioksidan ada tiga fraksi yang mempunyai aktivitas antioksidan dengan tertinggi masing- 
masing yaitu fraksi EA1 : 86,87 $\%$, EA6 : 93,64 \%, dan EA7 : $85,87 \%$, dan ditentukan fraksi 7 untuk dilanjutkan untuk kolom kedua dilihat dari banyak bobot fraksi yang didapat.

- Uji aktivitas antioksidan FEA.7.3 hasil kromatografi

\section{kolom 2}

Hasil dilihat dari aktivitas paling tinggi dengan dilihat persen hambat yaitu ada pada F-EA.7.3 dengan persen hambat $93,05 \%$ bhasil uji bisa dilihat pada Tabel 2 .

Tabel 2. Persen hambat uji antioksidan 2

\begin{tabular}{|c|c|c|}
\hline NO & SAMPEL & $\begin{array}{c}\text { PEREDASMA } \\
\mathrm{N}(\%)\end{array}$ \\
\hline 1 & F-EA.7.2 & 82,25 \\
\hline 2 & F-EA.7.3 & 93,05 \\
\hline 3 & F-EA.7.4 & 54,97 \\
\hline 4 & F-EA.7.5 & 13,46 \\
\hline
\end{tabular}

- Identifikasi Senyawa Kimia

Berdasarkan data spektrofotometri $\quad{ }^{1} \mathrm{H}-\mathrm{NMR}$ (Gambar 1) menunjukkan bahwa isolat EA 7.3.1 memiliki 1 buah puncak proton pada daerah aromatik $\delta_{\mathrm{H}}(\mathrm{ppm})$ 7,10 (s, 2H, H-3/H-6) dengan intensitas 2 buah proton, 1 buah puncak khas untuk gugus metoksi $\left(-\mathrm{OCH}_{3}\right)$ (singlet dengan intensitas kuat) pada $\delta_{\mathrm{H}}(\mathrm{ppm}) 3,78$ (s, 3H, H-7), 1 buah puncak proton pada daerah $\delta_{\mathrm{H}}(\mathrm{ppm})$ 8,01 dengan multiplisitas singlet (s) kemungkinan besar merupakan puncak pergeseran kimia dari gugus hidroksil $(-\mathrm{OH})$ yang terikat pada cincin aromatik, serta puncak-puncak khas atau typical untuk gugus asam lemak (alkana) pada $\delta_{\mathrm{H}}(\mathrm{ppm}) 0,88(\mathrm{t}, 3 \mathrm{H}, \mathrm{H}-10$ ' ($\left.\mathrm{CH}_{3}\right)$ ), 1,29 (bs, 12H, H-4'-H9' 6( $\left.\left(\mathrm{CH}_{2}\right)\right), 1,59\left(\mathrm{~m}, 2 \mathrm{H}, \mathrm{H}-3^{\prime}\left(\mathrm{CH}_{2}\right)\right)$, dan $2.29\left(\mathrm{t}, 2 \mathrm{H}, \mathrm{H}-2^{\prime}\left(\mathrm{CH}_{2}\right)\right)$.

Berdasarkan data hasil analisa ${ }^{1} \mathrm{H}-$ NMR tersebut, patut diduga bahwa isolat EA-7.3.1 memiliki 1 buah cincin aromatik dalam bentuk senyawa fenolik yang mengikat 2 buah substituen berbeda yaitu gugus metoksi dan gugus asam lemak hasil ${ }^{1}$ H-NMR bisa dilihat pada Gambar 1.

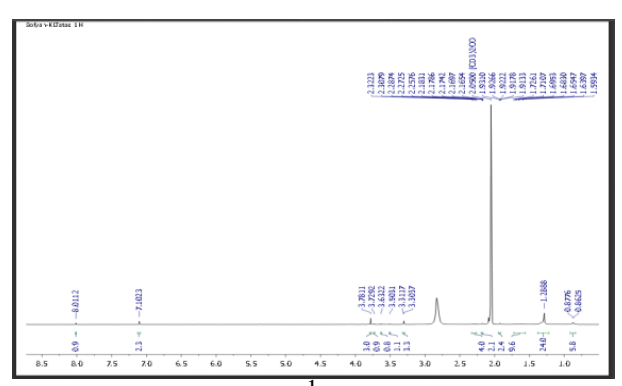

Gambar 1. Spektrum ${ }^{1} \mathrm{H}-\mathrm{NMR}$ isolat EA 7.3.1 
Berdasarkan data hasil analisa FT-IR dan ${ }^{1} \mathrm{H}-\mathrm{NMR}$ yang dilakukan terhadap isolat EA-7.3.1 patut di duga bahwa isolat EA7.3.1 merupakan senyawa fenolik yang mempunyai 2 buah substituen berbeda, yaitu gugus metoksi ( -OCH3 ) yang terikat pada atom C-4 dan gugus asam lemak yang terikat pada atom $\mathrm{C}-1$ gambar bisa dilihat pada Gambar 2.

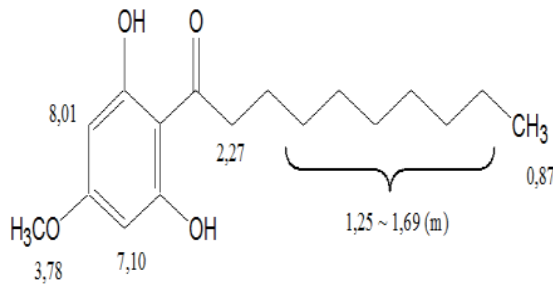

Gambar 2 Struktur

Kimia senyawa fraksi EA 7.3.1

Untuk memastikan bobot molekul dari isolat EA-7.3.1 diperlukan analisa lanjutna untuk memperoleh bobot molekul (BM) dari senyawa isolat EA-7.3.1 Analisis BM dilakukan menggunakan Kromatografi GC dengan spektrum hasil analisa terlihat pada Gambar 3
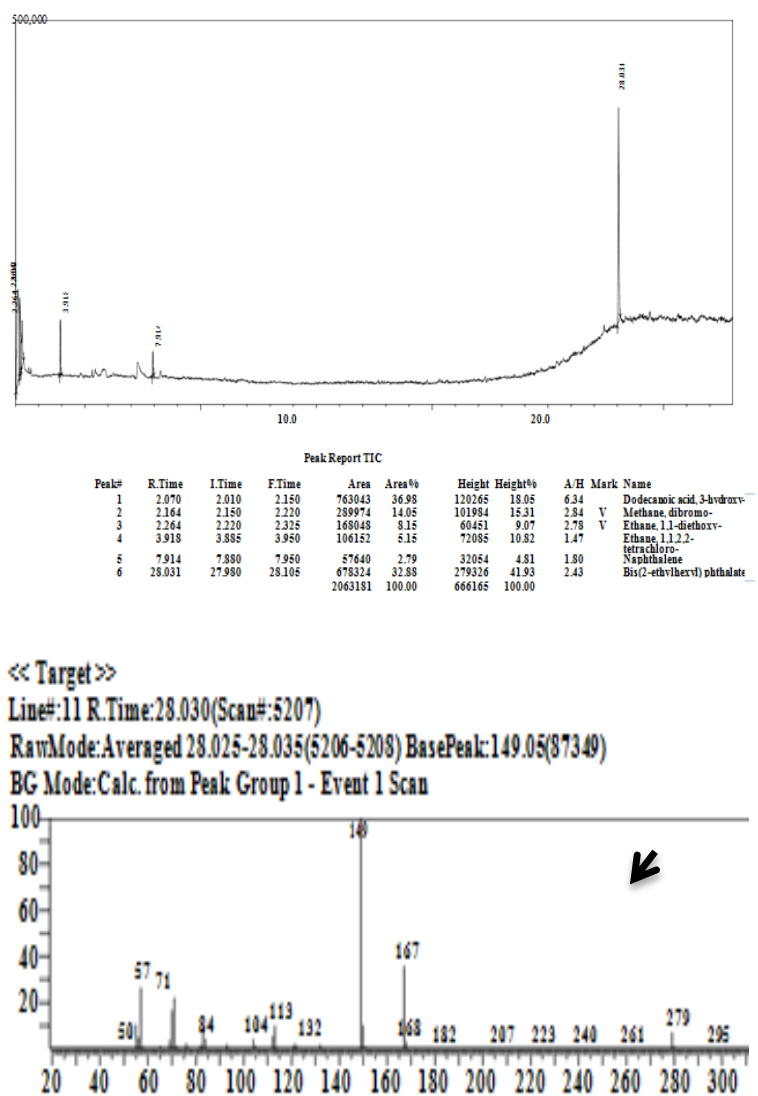

Gambar 3. KG-SM isolat 7.3.1

Berdasarkan data yang diperoleh dari hasil analisis BM terhadap isolat EA-7.3.1, diperoleh data bahwa isolat EA-7.3.1 dengan kondisi analisis yang dilakukan memiliki waktu retensi (Rf) 28.03 menit, dengan intensitas puncak paling tinggi.

Adapun pada waktu retensi tersebut, bobot molekul yang ditunjukkan adalah (m/z) $295[\mathrm{M}+1]$ atau $[\mathrm{M}+\mathrm{H}]$, yang berarti bahwa bobot molekul $[\mathrm{M}+]$ dari isolat EA7.3.1 adalah $(\mathrm{m} / \mathrm{z})$ 294. Munculnya 
nilai $[\mathrm{M}+1], \quad[\mathrm{M}+2], \quad$ dan seterusnya sebagai akibat dari adanya isotop dari masingmasing atom, sebagai contoh

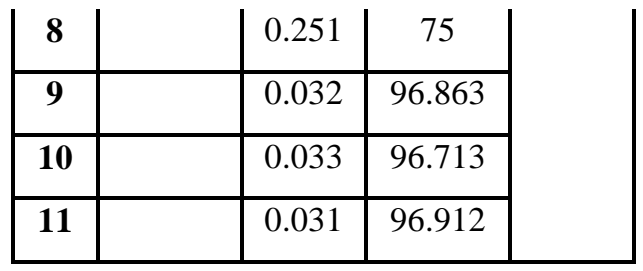
adalah atom ${ }^{12} \mathrm{C}$ yang mempunyai jumlah kelimpahan di alam sebesar 98.9\%, serta kelimpahan isotopnya ${ }^{13} \mathrm{C}$ yang hanya sebesar $1,10 \%$. Adanya isotop ${ }^{13} \mathrm{C}$ inilah yang menyebabkan adanya nilai $[\mathrm{M}+1],[\mathrm{M}+2]$, dan seterusnya dalam hasil analisisis isolat murni.

Setelah diidentifikasi senyawa dan diapatkan isolat murni dilanjutkan uji aktivitas antioksidan $\mathrm{IC}_{50}$ dan bisa dilihat pada tabel dan gambar.

Tabel 3. Hasil Uji Antioksidan $\mathrm{IC}_{50}$

\begin{tabular}{|c|c|c|c|c|}
\hline No & $\begin{array}{c}\text { Sampe } \\
1\end{array}$ & $\begin{array}{l}\text { rata- } \\
\text { rata }\end{array}$ & $\begin{array}{c}\% \\
\text { hamba } \\
\mathbf{t}\end{array}$ & $\mathbf{I C}_{50}$ \\
\hline 1 & Blanko & 1.004 & & \multirow{6}{*}{$\begin{array}{c}297,7 \\
9\end{array}$} \\
\hline 2 & $\begin{array}{c}\text { Fr } \\
7.3 .1\end{array}$ & 0.955 & 4.88 & \\
\hline 3 & & 0.95 & 5.428 & \\
\hline 4 & & 0.887 & 11.653 & \\
\hline 5 & & 0.85 & 15.339 & \\
\hline 6 & & 0.813 & 19.024 & \\
\hline 7 & Vit C & 0.731 & 27.241 & 1,455 \\
\hline
\end{tabular}

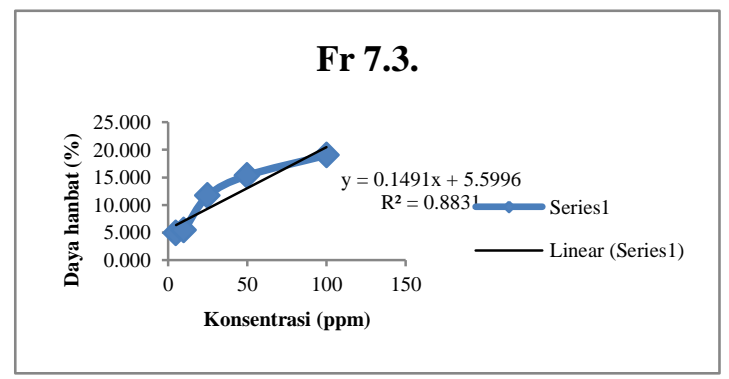

Gambar 4. Grafik hubungan antara konsentrasi (bpj) dengan persen inhibisi (\%) uji aktivitas antioksidan dengan peredamna radikal bebas DPPH fraksi 7.3.

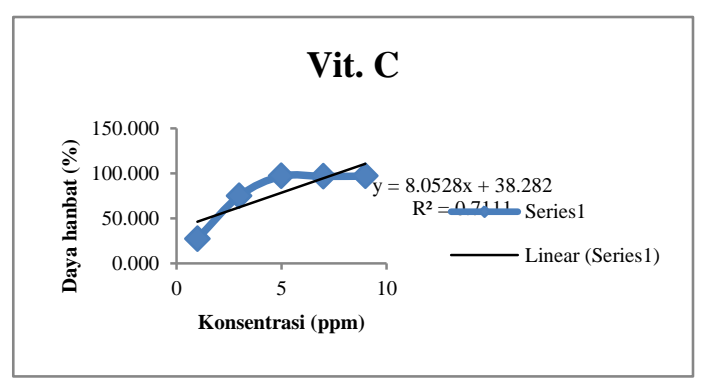

Gambar 4. Grafik hubungan antara konsentrasi (bpj) dengan persen inhibisi (\%) uji aktivitas antioksidan dengan peredaman radikal bebas DPPH Vitamin C.

\section{KESIMPULAN}

Berdasarkan hasil isolasi dan purifikasi, yang dilanjutkan dengan proses identifikasi berdasarkan data hasil analisa FT-IR, ${ }^{1}$ H-NMR dan GC-MS, dapat disimpulkan bahwa diduga kulit 
buah jengkol dari ekstrak etil asetat mengandung senyawa metabolit sekunder dari golongan fenolik 1-(2,6-dihidroksi-4metoksfenil)dekan-1-on

(IUPAC:1-(2,6-dihydroxy-4methoxyphenyl)decan-1-one) yang mempunyai bobot molekul $\mathrm{m} / \mathrm{z}$ 294, dan tidak aktif sebagai senyawa antioksidan dengan nilai $\mathrm{IC}_{50} 297,79 \mu \mathrm{g} / \mathrm{mL}$.<smiles>CCCCCCCCCC(=O)c1c(O)cc(OC)cc1O</smiles>

\section{UCAPAN TERIMA KASIH}

Ucapan terimakasih kami haturkan kepada Tuhan Yang Maha Esa atas ilmu yang diberikan kepada saya, juga kepada kedua pembimbing saya bapak Prof. (ris) Dr. Partomuan simanjuntak, M.Sc. dan bapak Dr. Ahmad Darmawan, M.Si.

\section{DAFTAR PUSTAKA}

World Health Organization.

Traditional Medicine. 2003

Kotranas. 2006. Ramuan Pusaka Nusantara, Kekayaan Bangsa yang Harus Dipelihara.

Anonim, Atasi jentik DBD dengan kulit jengkol. (2009).

Winarsi H. 2007. Antioksidan alami dan radikal. Penerbit Kanisius. (Edisi 4-10 juli 2012 No.3646 Tahun XLII 2 Agroinovasi Badan Litbang Pertanian). H.11-36, 77-82

Sofia D.antioksdian dan radikal bebas; 2003

Nurussakinah. Skrinning Fitokimia dan Uji Aktivitas Antibakteri Ekstrak Kulit Buah Tanaman Jengkol (Archidendron Pauciflorum (Benth.) I.C Nielsen) Terhadap Bakteri Streptococcus mutans, Staphylococcus aureus, dan Eschericia coli, Skripsi, Fakultas Farmasi, USU, Medan; 2010.

Surya Alfian Aktivitas Ekstrak Kulit buah Jengkol (pitecellebium jiringa) dengan Tiga Pelarut yang Berbeda Kepolarannya: Pekanbaru.2017

Verdiani, Devi. Isolasi DanIdentifikasi Senyawa Antioksidan Dari Ekstrak Etanol 96\% Kulit buah jengkol (Archidendron Pauciflorum (Benth.) I.C Nielsen). Jakarta. 2018. 